Aim of the study: To evaluate the diagnostic capacity of tele-cervicography for the detection of cervical neoplasia as an adjunctive test with Papanicolaou (Pap) smears.

Material and methods: Pap smear and tele-cervicography were performed on each subject. Histologic results were obtained for all patients.

Results: Of the 863 females who had a tele-cervigram, 252 (29.2\%) had a positive result. Of the 60 histologically confirmed cases of high-grade squamous intraepithelial lesions (HSILs), $56(93.3 \%)$ were detected by tele-cervicography, including 16 (26.7\%) with a positive grade of 1 and 40 (66.7\%) with a positive grade of 2 . With the positive threshold of tele-cervicography set as any positive grade (PO to P3), the overall sensitivity was $94.0 \%$ (95\% Cl: 88.0-97.3\%), the specificity was $80.9 \%$ (95\% Cl: $80.0-81.5 \%)$, and the positive likelihood ratio was 4.94 (95\% Cl: 4.23-5.77) for the detection of HSILs or cancer. The combination of tele-cervicography with Pap smear testing for the detection of HSILs or cancer resulted in an increase in sensitivity from $84.6 \%$ (Pap only: cutoff = atypical squamous cells of undetermined significance or more severe) to $98.3 \%$ (Pap plus tele-cervicography: cutoff $=\mathrm{PO}$ or more severe).

Conclusions: The sensitivity of tele-cervicography was higher than that of cytology for the detection of cervical neoplasia, and combining the two tests increased the sensitivity. Tele-cervicography can be considered a useful complementary tool to cytology.

Key words: cervicography, cervical cancer, cervical neoplasia, screening.

Contemp Oncol (Pozn) 2016; 20 (5): 402-406 DOI: $10.5114 /$ wo.2016.64604

\section{The performance of tele- cervicography for detection of preinvasive and invasive disease of the uterine cervix as an adjunctive test to Pap smears}

Kyehyun Nam ${ }^{1}$, Soo-Nyung Kim², Seung-hyuk Sim², Seijun $\mathrm{Han}^{3}$

'Department of Obstetrics and Gynecology, Soonchunhyang University Hospital, Bucheon, South Korea

${ }^{2}$ Konkuk University Medical Center, Seoul, South Korea

${ }^{3}$ Chosun University Hospital, Gwangju, South Korea

\section{Introduction}

It is well recognised that cytological screening to detect preinvasive and early invasive cancer of the uterine cervix has led to a dramatic decline in the incidence of cervical cancer mortality in several countries [1]. The incidence of cervical cancer has fallen by $50 \%$ or more since the introduction of Papanicolaou (Pap) smear screening in countries that perform cervical cancer screening [2]. The false-negative rates of Pap smears are considerable, ranging from $15 \%$ to $30 \%$ for high-grade lesions [3]. False-negative rates for invasive cervical cancer can be even higher, approaching 50\% in some series. Concerns regarding errors in conventional Pap smears have motivated some researchers to evaluate alternate or adjunctive screening methods [4].

One adjunctive screening method is cervicography. In 1981, Adolf Stafl described a cervicography method and recommended its use as an adjunctive tool with Pap smears for the primary screening of cervical cancer [5]. Cervicography can be used in combination with cytological examination to screen the general population. The higher sensitivity of cervicography compared with a Pap smear was confirmed in other series, and led to the recommendation of cervicography as a complementary test to cytology [6].

The prototype cervicography system was equipped with a $35-\mathrm{mm}$ camera and film [5]. This process, from taking the photographs to reporting the results to physicians, including the development of films, mounting the slides, and reading in the dark room, was both complex and laborious. Recently, the tele-cervicography system was developed. The entire cervicography process was conducted through the Internet. The present study aimed to evaluate tele-cervicography as a primary screening method and as an adjunct to the Pap smear for the early detection of preinvasive and invasive cancer of the uterine cervix. This study focused on the performance of tele-cervicography, omitting the inconvenience of proto-type cervicography.

\section{Material and methods}

Patients

Cervical cytology and tele-cervicography were performed on 3065 female patients at the gynaecological cancer clinic at Konkuk University Hospital between August 2005 and January 2010. Of the 3065 females, 863 were eligible for analysis. The inclusion criteria were asymptomatic non-pregnant females who presented for gynaecological examination. Females with a previous abnormal Pap smear within the past 12 months, who received treatment 
for CIN, or who had undergone a total hysterectomy before the examination were excluded. Institutional approval was obtained from the Ethics Committee for Medical Research of the Hospital of Konkuk University. Because of the retrospective nature of the study, the requirement for informed consent was waived.

\section{Conventional Pap smear}

A Pap smear was carried out using a wooden Ayre spatula in combination with a cytobrush (Medland, Seoul, Korea). All specimens were stained using the Papanicolaou method and were classified according to the Bethesda system. The positive cut-off grades of the Pap smear test were classified as ASCUS or more severe and LSIL or more severe.

\section{The tele-cervicography procedure}

After collecting the cytological specimen, two tele-cervigram images were obtained. Acquisition of the tele-cervigram images was as for conventional cervigrams. Firstly, $5 \%$ acetic acid was applied to the cervix after removing mucus or discharges. Next, the first image was obtained 30 seconds after acetic acid application. A second acetic acid application to the cervix was carried out, and another image was taken after 15 seconds. The images were transmitted to a server via the Internet for immediate evaluation. Transmitted images were evaluated on a video monitor. The tele-cervigrams were evaluated by certified evaluators who had passed the level II or higher test of the National Testing Laboratories worldwide (St Louis, MO, USA) for evaluation of cervicography (Fig. 1). The criteria for reading the tele-cervigrams were as for conventional cervicography diagnostic criteria approved by National Testing Laboratories worldwide, as noted in Table 1. The positive cut-off grades were classified as atypical or more severe and PO or more severe.

\section{Data analysis}

The sensitivity, specificity, and positive likelihood ratio of tele-cervicography were calculated using the biopsy result

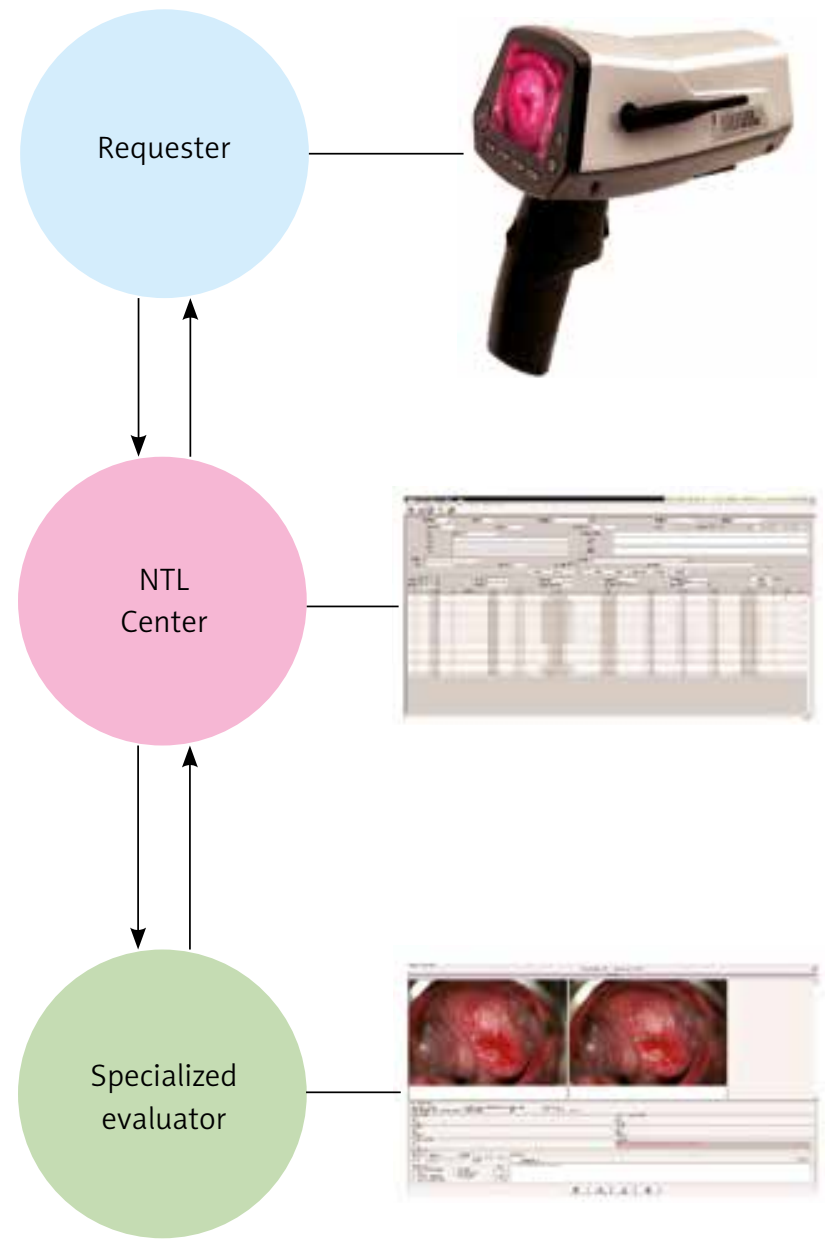

Fig. 1. The internet network system of digital tele-cervicography

as the 'gold standard'. Likelihood ratios are a useful and practical way of expressing the power of a diagnostic test [7], and are independent of disease prevalence. Two different definitions of disease were used as targets for screening: (1) disease is an HSIL or cancer (vs. a normal, equivocal, or low-grade squamous intraepithelial lesion); (2) disease is an LSIL, an HSIL, or cancer (vs. a normal or equivocal lesion).

Table 1. Tele-cervicography diagnostic classification

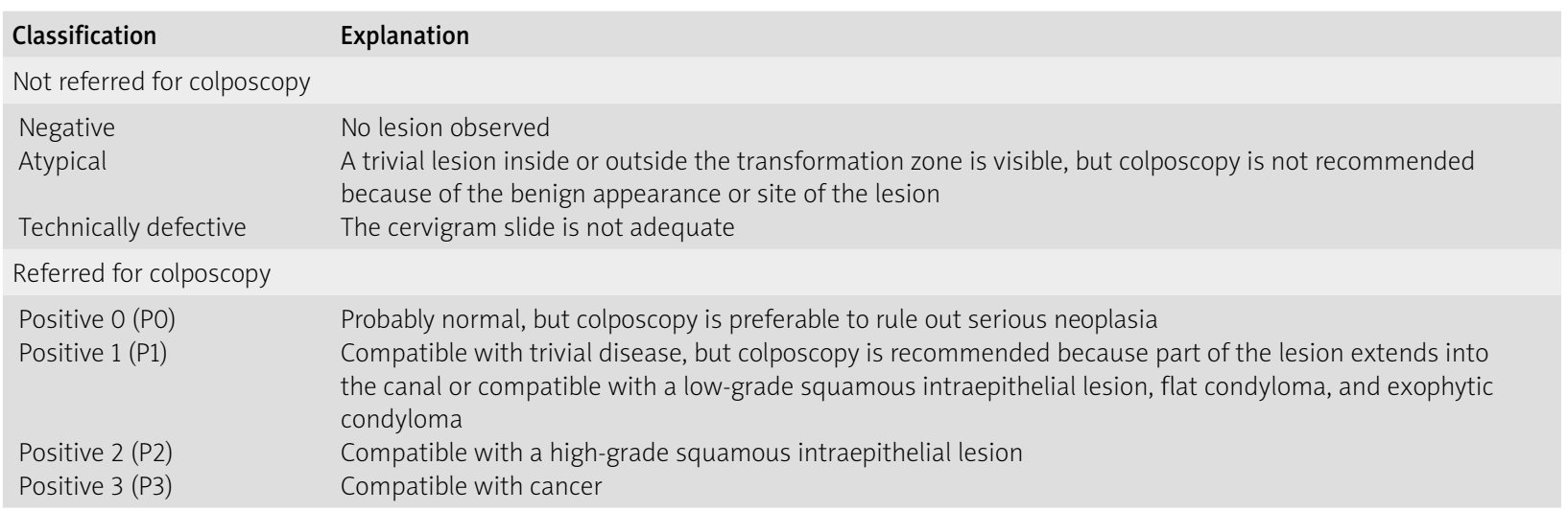

The above classification was released on January 1, 1995 by National Testing Laboratories worldwide. The current terminology was applied to all tele-cervigram classifications in this study. 
Table 2. Patients' characteristics $(n=863)$

\begin{tabular}{|c|c|c|}
\hline & Characteristic & Value \\
\hline Age (years) & & $48.3 \pm 10.5(23-85)$ \\
\hline Age group & $\begin{array}{l}<50 \text { years } \\
\geq 50 \text { years }\end{array}$ & $\begin{array}{l}470 \\
393\end{array}$ \\
\hline Pap cytology & $\begin{array}{c}\text { WNL } \\
\text { ASCUS } \\
\text { AGC } \\
\text { ASC-H } \\
\text { LSIL } \\
\text { HSIL } \\
\text { Cancer }\end{array}$ & $\begin{array}{c}500(57.9) \\
144(16.7) \\
4(0.5) \\
6(0.7) \\
125(14.5) \\
61(7.1) \\
23(2.7)\end{array}$ \\
\hline $\begin{array}{l}\text { Tele-cervicography } \\
\text { results }\end{array}$ & $\begin{array}{c}\text { Negative } \\
\text { Atypical } \\
\text { Positive } 0 \\
\text { Positive } 1 \\
\text { Positive } 2 \\
\text { Positive } 3\end{array}$ & $\begin{array}{c}512(59.3) \\
99(11.5) \\
12(1.4) \\
147(17.0) \\
66(7.6) \\
27(3.1)\end{array}$ \\
\hline Biopsy results & $\begin{array}{c}\text { Cervicitis } \\
\text { Koilocytosis } \\
\text { CIN } 1 \\
\text { CIN } 2 \\
\text { CIN } 3 \\
\text { Cancer }\end{array}$ & $\begin{array}{c}551(63.8) \\
13(1.5) \\
182(21.1) \\
7(0.8) \\
53(6.1) \\
57(6.6)\end{array}$ \\
\hline
\end{tabular}

WNL - within normal limits; ASCUS - atypical squamous cells of undetermined significance; AGC - atypical glandular cells; ASC-H - atypical squamous cells, cannot exclude HSIL; LSIL - low-grade squamous intraepithelial lesion; HSIL high-grade squamous intraepithelial lesion; CIN-cervical intraepithelial neoplasia

Two thresholds to define a positive tele-cervigram result were examined for analytical purposes, including (1) a positive grade of P0, P1, P2, or P3 (vs. an atypical or a negative tele-cervigram result) and (2) an atypical or a more severe positive (vs. negative) tele-cervigram result. Analyses of sensitivity and specificity were conducted using standard contingency table methods. Tables were stratified by age. Tele-cervicography was directly compared with conventional cytological screening based on the threshold level for ASCUS or more severe and LSIL or more severe.

\section{Statistical analysis}

The data were computerised and analysed using SPSS ver. 19 (SPSS, Inc., Chicago, IL, USA). The diagnostic accu- racy of each test was calculated based on the sensitivity, specificity, and the positive likelihood ratio and the EpiMax Table Calculator (http://www.healthstrategy.com). The sensitivity of cytology and tele-cervicography for the detection of HSIL or cancer was analysed using McNemar's test (http://vassarstats.net/propcorr.htm). All p-values presented are two-tailed; a value of $p<0.05$ was taken to indicate statistical significance.

\section{Results}

\section{Patients' characteristics}

The average age of the 863 patients was $48.3 \pm 10.5$ years (range: $23-85$ years), and their characteristics are summarised in Table 2. Pap smear, tele-cervigram, and biopsy results are summarised in Table 2.

\section{Diagnostic potential of tele-cervicography and the Pap smear}

The distribution of pathologic diagnosis according to the tele-cervigram result is presented in Table 3. Of the 863 females who had a tele-cervigram, 252 (29.2\%) had a positive result. Fifty-four cases (94.7\%) of 57 invasive cancers were detected by tele-cervicography. Of the histologically confirmed cases of HSILs, 56 (93.3\%) were detected by tele-cervicography, including 16 (26.7\%) with a positive 1 tele-cervigram and 40 (66.7\%) with a positive 2 tele-cervigram (Table 3). The sensitivity, specificity, and positive likelihood ratio of tele-cervicography for the detection of HSILs or cancer are presented in Table 4. With a positive threshold of tele-cervicography as any positive result (PO to P3), the overall sensitivity of the tele-cervigram was 94.0\% (95\% Cl: 88.0-97.3\%), the specificity was 80.9\% (95\% Cl: 80.0-81.5\%), and the positive likelihood ratio 4.94 (95\% Cl: 4.23-5.77) (Table 4).

\section{Diagnostic potential of the Pap smear}

The sensitivity of the Pap smear for the detection of HSILS or cancer using a threshold of ASCUS or more severe was $84.6 \%$ (95\% Cl: 77.0-90.0\%), the specificity was $64.4 \%$ (95\% Cl: 61.1-68.0\%), and the positive likelihood ratio was 2.39 (95\% Cl: 2.112-2.707) (Table 5). Tele-cervicography combined with the Pap smear for the detection

Table 3. Distribution of final pathology results by tele-cervicography

\begin{tabular}{|c|c|c|c|c|c|c|c|}
\hline \multirow{2}{*}{$\begin{array}{l}\text { Tele-cervicography } \\
\text { result* }\end{array}$} & \multicolumn{7}{|c|}{ Final pathology } \\
\hline & $\begin{array}{l}\text { Normal } \\
\text { (No, \%) }\end{array}$ & $\begin{array}{l}\text { Koilocytosis } \\
\text { (No, \%) }\end{array}$ & $\begin{array}{c}\text { CIN } 1 \\
(\text { No, \%) }\end{array}$ & $\begin{array}{c}\text { CIN } 2 \\
(\text { No, \%) }\end{array}$ & $\begin{array}{l}\text { CIN } 3 \\
(\text { No, \%) }\end{array}$ & $\begin{array}{l}\text { Cancer } \\
\text { (No, \%) }\end{array}$ & $\begin{array}{c}\text { Total } \\
(\text { No, \%) }\end{array}$ \\
\hline Negative & 487 (88.4) & $1(7.7)$ & $23(12.6)$ & $0(0.0)$ & $0(0.0)$ & $1(1.8)$ & $512(59.3)$ \\
\hline Atypical & $39(7.1)$ & $5(38.5)$ & $49(26.9)$ & $0(0.0)$ & $4(7.5)$ & $2(3.5)$ & 99 (11.5) \\
\hline Positive 0 & $2(0.4)$ & $0(0.0)$ & $3(1.6)$ & $0(0.0)$ & $0(0.0)$ & $7(12.3)$ & $12(1.4)$ \\
\hline Positive 1 & $22(4.0)$ & $7(53.8)$ & $100(54.9)$ & $5(71.4)$ & $11(20.8)$ & $2(3.5)$ & $147(17.0)$ \\
\hline Positive 2 & $0(0.0)$ & $0(0.0)$ & $7(3.8)$ & $2(28.6)$ & 38 (71.7) & $19(33.3)$ & $66(7.6)$ \\
\hline Positive 3 & $1(0.2)$ & $0(0.0)$ & $0(0.0)$ & $0(0.0)$ & $0(0.0)$ & $26(45.6)$ & 27 (3.1) \\
\hline Total & 551 & 13 & 182 & 7 & 53 & 57 & $863(100.0)$ \\
\hline
\end{tabular}

CIN - cervical intraepithelial neoplasia.

The tele-cervicography classification scheme is provided in Table 1. 
Table 4. Sensitivity and specificity of tele-cervicography for the detection of HSILs or cancer

\begin{tabular}{|c|c|c|c|c|c|c|c|c|c|}
\hline & & \multirow{3}{*}{$\begin{array}{l}\text { No. with } \\
\text { HSILs or } \\
\text { cancer }\end{array}$} & \multirow[t]{3}{*}{ Total } & \multicolumn{6}{|c|}{ Threshold level } \\
\hline & & & & \multicolumn{3}{|c|}{$\begin{array}{c}\text { Referred for tele-cervicography if atypical } \\
\text { or more severe }\end{array}$} & \multicolumn{3}{|c|}{$\begin{array}{l}\text { Referred for tele-cervicography if PO } \\
\text { or more severe }\end{array}$} \\
\hline & & & & $\begin{array}{l}\text { Sensitivity } \\
(\%)\end{array}$ & $\begin{array}{l}\text { Specificity } \\
\text { (\%) }\end{array}$ & $\begin{array}{l}\text { Positive } \\
\text { LR }\end{array}$ & $\begin{array}{c}\text { Sensitivity } \\
(\%)\end{array}$ & $\begin{array}{l}\text { Specificity } \\
(\%)\end{array}$ & $\begin{array}{l}\text { Positive } \\
\text { LR }\end{array}$ \\
\hline Overall & & 117 & 863 & 99.1 & 68.4 & 3.15 & 94.0 & 80.9 & 4.94 \\
\hline \multirow{2}{*}{$\begin{array}{l}\text { Age } \\
\text { group }\end{array}$} & $<50$ years & 69 & 470 & 99.3 & 57.9 & 2.36 & 95.7 & 75.6 & 3.91 \\
\hline & $\geq 50$ years & 48 & 393 & 97.9 & 80.9 & 5.12 & 91.7 & 87.2 & 7.19 \\
\hline
\end{tabular}

HSIL - high-grade squamous intraepithelial lesion; $L R$ - likelihood ratio

Table 5. Sensitivity and specificity of Pap cytology for the detection of HSILs or cancer

\begin{tabular}{|c|c|c|c|c|c|c|c|c|c|}
\hline & & \multirow{3}{*}{$\begin{array}{l}\text { No. with } \\
\text { HSIL or } \\
\text { cancer }\end{array}$} & \multirow[t]{3}{*}{ Total } & \multicolumn{6}{|c|}{ Threshold level } \\
\hline & & & & \multicolumn{3}{|c|}{$\begin{array}{c}\text { Positive Pap cytology if ASCUS } \\
\text { or more severe }\end{array}$} & \multicolumn{3}{|c|}{$\begin{array}{c}\text { Positive Pap cytology if LSIL } \\
\text { or more severe }\end{array}$} \\
\hline & & & & $\begin{array}{c}\text { Sensitivity } \\
(\%)\end{array}$ & $\begin{array}{l}\text { Specificity } \\
(\%)\end{array}$ & Positive LR & $\begin{array}{l}\text { Sensitivity } \\
\text { (\%) }\end{array}$ & $\begin{array}{l}\text { Specificity } \\
(\%)\end{array}$ & $\begin{array}{l}\text { Positive } \\
\text { LR }\end{array}$ \\
\hline Overall & & 117 & 863 & 84.6 & 64.6 & 2.39 & 60.7 & 81.5 & 3.26 \\
\hline \multirow{2}{*}{$\begin{array}{l}\text { Age } \\
\text { group }\end{array}$} & $<50$ years & 69 & 470 & 84.1 & 56.1 & 1.91 & 49.3 & 77.1 & 2.15 \\
\hline & $\geq 50$ years & 48 & 393 & 85.4 & 74.5 & 3.34 & 77.1 & 86.7 & 5.78 \\
\hline
\end{tabular}

ASCUS - atypical squamous cells of undetermined significance; LSIL - low-grade squamous intraepithelial lesion; LR - likelihood ratio

of HSILS or cancer showed an increased sensitivity from $84.6 \%$ of Pap only (ASCUS or more severe) to $98.3 \%$ (95\% Cl: 94.0-99.5\%) (Pap plus tele-cervicography [P0 or more severe]) (Table 6). Regarding the detection of LSIL or more severe lesions, tele-cervicography showed similar results when used in combination with Pap cytology (Table 6).

\section{Discussion}

Telemedicine can be applied to healthcare for many people, particularly those living outside of urban areas [8]. The application of telemedicine to colposcopy or telecolposcopy has been reported and suggests that telecolposcopy can enable distant colposcopy experts to remotely examine females with cervical neoplasia [9, 10]. Telecolposcopy using digitalised colposcopic images can be applied to colposcopy quality control by remote review [11]. Tele-cervicography is one example of digital cervicography. Our system is different from digital cervicography of previous papers. We designed Internet-based software for the evaluation of digitalised cervical images. Soon after being obtained by digital cervicography, the cervical images were sent to a certified evaluator at a distant location through an Internet-based central server.

In our study, the tele-cervigram results were positive (PO to P3) in 252 (29.2\%) of 863 patients. This rate is higher than the positive rate of cervicography among the screened general population, which ranges from 3.1\% to $10.6 \%[4,6,12]$. The cause may be that the target population was different, and our study was not designed for cervicography screening. The goal of our study was to evaluate the diagnostic capacity of tele-cervicography.

Our results showed that the final pathologic distribution of 66 females with a positive 2 comparable with CIN
Table 6. Sensitivity and specificity of Pap cytology combined with tele-cervicography for the detection of LSILs or more severe lesions and HSILs or cancer

\begin{tabular}{|c|c|c|c|}
\hline & $\begin{array}{l}\text { Sensitivity } \\
\text { (\%) }\end{array}$ & $\begin{array}{l}\text { Specificity } \\
\text { (\%) }\end{array}$ & $\begin{array}{c}\text { Positive } \\
\text { likelihood ratio }\end{array}$ \\
\hline \multicolumn{4}{|l|}{ HSILs or cancer $(n=117)$} \\
\hline $\begin{array}{l}\text { Pap smear only (ASCUS } \\
\text { or more severe) }\end{array}$ & 84.6 & 64.6 & 2.39 \\
\hline $\begin{array}{l}\text { Pap + Tele- } \\
\text { cervicography } \\
\text { (P0 or more severe) }\end{array}$ & 98.3 & 60.6 & 2.49 \\
\hline \multicolumn{4}{|c|}{ LSIL or more severe $(n=312)$} \\
\hline $\begin{array}{l}\text { Pap smear only (ASCUS } \\
\text { or more severe) }\end{array}$ & 85.6 & 82.6 & 4.91 \\
\hline $\begin{array}{l}\text { Pap smear + Tele- } \\
\text { cervicography (PO or } \\
\text { more severe) }\end{array}$ & 97.1 & 80.6 & 5.05 \\
\hline
\end{tabular}

ASCUS - atypical squamous cells of undetermined significance; LSIL low-grade squamous intraepithelial lesion; HSIL - high-grade squamous intraepithelial lesion.

2/3 was 7 (10.6\%) with CIN 1, 40 (60.6\%) with CIN 2/3, and 19 (28.8\%) with cancer. Of 27 females with a positive 3 comparable with cancer, 26 (96.3\%) were diagnosed with cancer. Our results are similar to those of previous reports of the diagnostic accuracy of cervicography results [4, 13]. The increasing tendency of diagnostic accuracy with increasing cervical pathology severity is confirmed by previous colposcopy studies [14, 15].

The overall sensitivity and specificity of tele-cervicography for the detection of HSILs or cancer by the threshold of any positive tele-cervigram (P0 to P3) were $94.0 \%$ and $80.9 \%$, respectively. The detection of high-grade lesions by 
cervicography is superior to that of low-grade lesions, as has been reported previously [16]. The sensitivity is higher than that in other studies, ranging from $49.5 \%$ to $58.2 \%$ in screening the general population [4, 12].

The significant increase in sensitivity that resulted from combining the two screening tools in this study has important implications for the screening program in terms of avoiding false-negative diagnosis of fatal cervical cancer. The combination of the Pap smear and tele-cervicography increased the sensitivity from $84.6 \%$ to $98.3 \%$ for the detection of HSILS or cancer, similar to those in previous reports [17-20]. The combination of tele-cervicography with Pap smear will decrease the false-negative rate of Pap smear alone for cervical cancer screening.

A limitation of this study was that the population was not a general screening population; thus the results do not represent screening characteristics. Additionally, to analyse the diagnostic accuracy of tele-cervicography, the exclusion of technically defective cases was not representative of the general practice of cervicography. The advantages of this study were that all subjects had results of cervical biopsy, revealing the diagnostic capacity of the Pap smear and tele-cervicography at one institution.

In conclusion, our data suggest that tele-cervicography has a high-quality diagnostic capacity for the detection of uterine cervical neoplasia, provides high-resolution images, and allows rapid interpretation through Internet-based software. This study suggests that tele-cervicography can offer colposcopy services to medically underserved females by remotely located expert colposcopists. A largescale trial in an unscreened population should be carried out more rigorously to determine the sensitivity of this new device and assess its potential as a screening tool.

The authors declare no conflict of interest.

\section{References}

1. Parkin DM, Pisani P, Ferlay J. Global cancer statistics. CA Cancer J Clin 1999; 49: 33-64.

2. Kitchener HC, Castle PE, Cox JT. Achievements and limitations of cervical cytology screening. Vaccine 2006; 24 Suppl 3: S63-S70.

3. Nanda K, McCrory DC, Myers ER, Bastian LA, Hasselblad V, Hickey JD, Matchar DB. Accuracy of the Papanicolaou test in screening for and follow-up of cervical cytologic abnormalities: a systematic review. Ann Intern Med 2000; 132: 810-9.

4. Schneider DL, Herrero R, Bratti C, et al. Cervicography screening for cervical cancer among 8460 women in a high-risk population. Am J Obstet Gynecol 1999; 180: 290-8.

5. Stafl A. Cervicography: a new method for cervical cancer detection. Am J Obstet Gynecol 1981; 139: 815-25.

6. Sutter P, Coibion M, Vosse M, Hertens D, Huet F, Wesling F, Wayembergh M, Bourdon C, Autier Ph. A multicentre study comparing cervicography and cytology in the detection of cervical intraepithelial neoplasia. Br J Obstet Gynaecol 1998; 105: 613-20.

7. Attia J. Moving beyond sensitivity and specificity: using likelihood ratios to help interpret diagnostic tests. Australian prescriber 2003; 26.

8. Bashshur RL. On the definition and evaluation of telemedicine. Telemed J 1995; 1: 19-30.

9. Harper DM, Moncur MM, Harper WH, Burke GC, Rasmussen CA, Mumford MC. The technical performance and clinical feasibility of telecolposcopy. J Fam Pract 2000; 49: 623-7.
10. Perisic Z, Rasic R, Raznatovic S. Quality and efficacy of a telecolposcopy programme. J Telemed Telecare 2005; 11: 20-2.

11. Ferris DG, Litaker MS. ASCUS/LSIL Triage Study (ALTS) Group. Colposcopy quality control by remote review of digitized colposcopic images. Am J Obstet Gynecol 2004; 191: 1934-41.

12. Denny L, Kuhn L, Pollack A, Wainwright H, Wright TC Jr. Evaluation of alternative methods of cervical cancer screening for resource poor settings. Cancer 2000; 89: 826-33.

13. De Vuyst H, Claeys P, Njiru S, et al. Comparison of pap smear, visual inspection with acetic acid, human papillomavirus DNA-PCR testing and cervicography. Int I Gynaecol Obstet 2005; 89: 120-126.

14. Hopman E, Kenemans P, Helmerhorst TJ. Positive predictive rate of colposcopic examination of the cervix uteri: an overview of literature. Obstet Gynecol Surv 1998; 53: 97-106.

15. Massad LS, Collins YC. Strength of correlations between colposcopic impression and biopsy histology. Gynecol Oncol 2003; 89: 424-8.

16. Franco ES, Hyppólito SB, Franco RGdFM, et al. Critérios de positividade para cervicografia digital: melhorando a sensibilidade do diagnóstico do câncer cervical Digital cervicography criteria: improving sensitivity in uterine cervical cancer diagnosis. Cad. Saúde Pública 2008; 24: 2653-60.

17. Cronjé HS, Cooreman BF, Beyer E, Bam RH, Middlecote BD, Divall PD. Screening for cervical neoplasia in a developing country utilizing cytology, cervicography and the acetic acid test. Int I Gynaecol Obstet 2001; 72: 151-7.

18. Baldauf JJ, Dreyfus M, Lehmann M, Ritter J, Philippe E. Cervical cancer screening with cervicography and cytology. Eur J Obstet Gynecol Reprod Biol 1995; 58: 33-9.

19. Cronjé HS, Parham GP, Cooreman BF, de Beer A, Divall P, Bam RH. A comparison of four screening methods for cervical neoplasia in a developing country. Am J Obstet Gynecol 2003; 188: 395-400.

20. Schneider A, Zahm DM, Kirchmayr R, Schneider VL. Screening for cervical intraepithelial neoplasia grade 2/3: validity of cytologic study, cervicography, and human papillomavirus detection. Am J Obstet Gynecol 1996; 174: 1534-41.

\section{Address for correspondence}

\section{Soo-Nyung Kim}

Konkuk University Medical Center 4-12 Hwayang-dong, Gwangjin-gu 143-729 Seoul, Korea (South) e-mail: snkim@chol.com

Submitted: 10.11.2014

Accepted: 11.06.2015 